\title{
Dynamic Compression Durability of Textile Pressure Sensor
}

\author{
MuraKami Tetsuhiko ${ }^{\mathrm{a}, *}$, MASUdA Atsuji ${ }^{\text {a }}$, SASAJI Toshinori ${ }^{\mathrm{b}}$, \\ IEmoto Yoshiyuki ${ }^{b}$, Uematsu Hideyuki $^{b}$, TAnoue Shuichi $^{b}$ \\ a Industrial Technology Center of Fukui Prefecture, Kawaiwashizuka 61, Fukui, Fukui 910-0102, Japan \\ ${ }^{\mathrm{b}}$ Graduate School of Engineering, University of Fukui, Bunkyo, Fukui, Fukui 910-8507, Japan
}

Received 17 December 2015; accepted for publication 16 June 2016

\begin{abstract}
This paper shows the experimental results about the dynamic compression durability of a textile sensor. Results obtained are as follows; (1) There were few changes of the detective pressure of the textile sensor in one million repetitive compression numbers or less. (2) The repetitive compressions caused the deformation of electrically conductive yarn. And then, the detective pressure of the textile sensor increased with the compression number greater than two million. In addition, the non-detecting points also increased with the compression number greater than two million because of breakage of electrically conductive yarn by dynamic compression. (3) Pressure detection characteristics of the textile sensor before loading the dynamic compression were maintained in one million repetitive compression numbers or less.
\end{abstract}

Key Words: Textile sensor, Compression sensor, Electrically conductive yarn, Dynamic compression durability, Repetitive compression

\section{テキスタイルセンサーの動的圧縮耐久性 \\ 村上哲彦 ${ }^{\mathrm{a}, *}$, 増田敦士 ${ }^{\mathrm{a}}$, 佐々治俊典 ${ }^{\mathrm{b}}$, 家元良幸 ${ }^{\mathrm{b}}$, 植松英之 ${ }^{\mathrm{b}}$, 田上秀一 ${ }^{\mathrm{b}}$

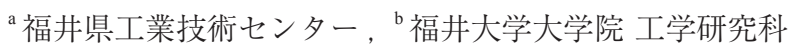

\section{1. 緒 言}

大面積の圧力を検知するシートセンサーは，柔軟性，伸縮 性, 厚み, 価格などの観点から様々な材料や方法により開発 されている [1].こうしたシートセンサーの一つとして，エ レクトロニクス技術とテキスタイル技術の特性を組み合わせ た $\mathrm{e}$-テキスタイル分野でもセンサーの開発が進められてい る。開発されているシートセンサーは, 主に静電容量法によ る織編物センサー [2-5]であるため電気回路の構成が繁雑で 使用環境の影響を受けやすい等の技術課題があり, これらの 問題を解決するためにPLLA 繊維を使用したシートセンサー [6] も検討されている.

こうした静電容量法以外のシートセンサーとして, 平二重 袋織物の上層部と下層部に導電糸を配置し, 織物の圧縮特性 を利用して圧力を検知できるテキスタイルセンサー（以下，
TS と呼称する）を福井県工業技術センターが開発している [7-9].この TS は導電糸の接触による通電で圧力を検知する ため, 静電容量法に比べると複雑な回路を構築する必要がな く，取り扱いが容易である。また，TS はテキスタイルの構 造でセンサー機能を構築しているため, センサーをテキス夕 イルに組み込む方法 $[10,11]$ と比べると, 薄層化が容易でセ ンサーの剥離がないため高耐久性であり, 製織工程おいてセ ンサー機能を構築できるため, 比較的安価に大面積化と量産 化が可能である。 そこで, 纎維企業で TS を応用した入退出 者数計測システムが実用化されており, 家庭用交流 $100 \mathrm{~V}$ 電 源での連続使用の他にバッテリー駆動にすることで, 設置場 所を自由に設定できる [12-14].

我々はこれまで TS の圧力検知応答性について報告してお り, 加圧時の応答性は $100 \mathrm{~ns}$, 除圧時の応答性は $400 \mathrm{~ns}$ と応 答性に優れているだけでなく, 繰り返し検知が可能である周

* 連絡先：福井県工業技術センター 910-0102 福井市川合熟塚町 61

E-mail : murakamitetsuhiko@fklab.fukui.fukui.jp, Tel : +81-776-55-0664, Fax : +81-776-55-0665 
波数の上限は $30 \mathrm{~Hz}$ であり, 感圧スイッチとして応用が可能 であることを明らかにした $[15]$ 。また，TS は平二重袋織物 の圧縮特性を利用したセンサーであるため，織物規格により TS が検知する圧力（以下，検知圧力と呼称する）を制御で き，導電糸本数を増加することで検知圧力のばらつきを抑制 できることを明らかにした $[16]$.さらに，TSのよこ糸が検 知圧力に及ぼす影響について検討し，よこ糸の種類を変える ことで検知圧力を制御できることを示唆した [17]. 加えて， TS を利用した実用的なシステムを開発するため，センサーと しての静的圧縮耐久性を検討し，低荷重であれば検知性能の 低下も少なく，除重後の検知性能もすみやかに回復すること を明らかにした [18]。しかし，前述の実用化事例のように 実際にシートセンサーとして TS が使用される場合は繰り返 し圧縮が想定されるため, 動的圧縮耐久性についての評価も 必要となる。そこで, 本報では TS に動的圧力の負荷をかけ たときの圧縮特性である動的圧縮耐久性と圧力検知応答性に ついて検討する.

\section{2. 実験方法}

\section{1 試 料}

本研究で使用する TS の織物規格を Table 1 に示す，導電糸 には芯糸にポリエステル糸, 鞘糸に銅線を使用したダブルカ バード糸を用いた，また，TSの構造を維持する地糸には芯 糸と同じポリエステル糸をたて糸およびよこ糸に使用して， レピア織機（津田駒工業製FR001）にて製作した。TSの断 面写真を Fig. 1 に示す。図のとおり，TS はたてよこ二重組 織による袋織物になっている。次に, 構造と圧縮挙動モデル を Fig. 2 に示す. TS の構造は Fig. 2(a) に示すとおり, 平二 重袋織物の上層部と下層部に導電糸を交錯, かつ接触しない ように配置している．TS が圧力を検知する原理を Fig. 2(b) に示す。この TS を圧縮したときに平二重袋織物の空間がつ ぶれ，上下に配置した導電糸が接触する。この時に, 導電糸 を含む電気回路には, 通電により電気信号の変化が生じるの で，この電気信号の変化をモニターすることで圧力を検知す

Table 1 Textile standard of the textile sensor used in this study.

\begin{tabular}{|c|c|}
\hline $\begin{array}{l}\text { Electrically } \\
\text { conductive } \\
\text { yarn }\end{array}$ & $\begin{array}{l}\text { Double covered yarn : } 3500 \text { twist } / \mathrm{m} \\
\text { Core : Polyester multi-filament } 330 \mathrm{dtex} / 96 \mathrm{f} \\
\\
450 \text { twist } / \mathrm{m} \\
\quad \text { (Toray Industries, Inc. Type 262) } \\
\text { Skin : Copper wire with a diameter of } 0.05 \mathrm{~mm} \\
\quad \text { (Sanshu Electric Wire Co., Ltd. Type A) }\end{array}$ \\
\hline $\begin{array}{l}\text { Ground } \\
\text { yarn }\end{array}$ & $\begin{array}{l}\text { Warp, Weft : } \\
\text { Polyester multi-filament } 330 \mathrm{dtex} / 96 \mathrm{f} \\
450 \text { twist } / \mathrm{m} \\
\quad \text { (Toray Industries, Inc. Type 262) }\end{array}$ \\
\hline Density & $\begin{array}{l}\text { Warp density : } 120 \text { ends/inch } \\
\text { Weft density : } 90 \text { picks/inch } \\
\text { In setting of weaving }\end{array}$ \\
\hline $\begin{array}{l}\text { Textile } \\
\text { structure }\end{array}$ & $\begin{array}{l}\text { Plane weave with double structure } \\
\text { Length of hollow : } 3.5 \mathrm{~mm}\end{array}$ \\
\hline
\end{tabular}

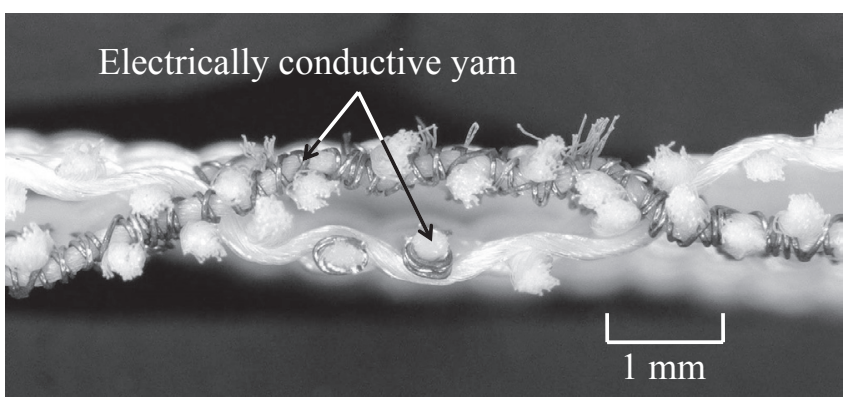

Fig. 1 Cross-sectional photograph perpendicular to weft yarn of the textile sensor.

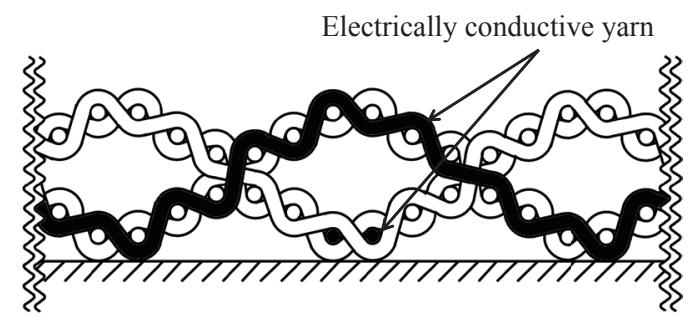

(a) Non-compression state

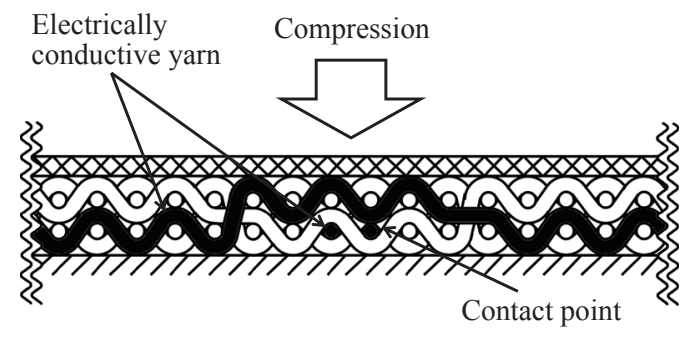

(b) Compression state

Fig. 2 Cross-sectional image perpendicular to weft yarn of the textile sensor.

ることができる。また，TS のたて糸の導電糸は約 $50 \mathrm{~mm}$ 間 隔で 2 本ずつ配置した。 よこ糸の導電糸は, 上層部が 6 本, 下層部が 6 本の平二重袋織物の 12 袋間隔で, Fig. 2 (a) に示 したように平二重袋織物の下層部中央に 2 本配置した。

\section{2 テキスタイルセンサーの動的圧縮試験評価}

TS の動的圧縮試験には, 疲労試験機（島津製作所製 EHFEV）を使用した. Fig. 3 に示すとおり, この TS の上下に塩化 ビニル製の板 (1 mm 厚) を設置し, 直径 $200 \mathrm{~mm}$ の加圧板 により $0 \sim 20 \mathrm{kPa}$ (荷重 $620 \mathrm{~N}$ ) の正弦波状の動的な繰り返 し圧力の負荷をかけた。過去の TS の圧力検知応答性の報告 [15）より，この TS の繰り返し検知が可能である周波数の上 限は $30 \mathrm{~Hz}$ であったため, 繰り返し周波数は確実に検知が可 能な周波数 $20 \mathrm{~Hz}$ に設定し, 繰り返し圧縮回数を最大 1,000 


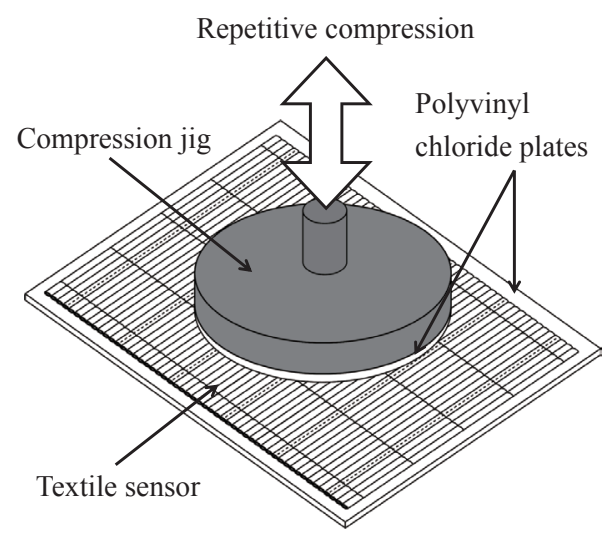

Fig. 3 Illustration of the dynamic compression test for the textile sensor.

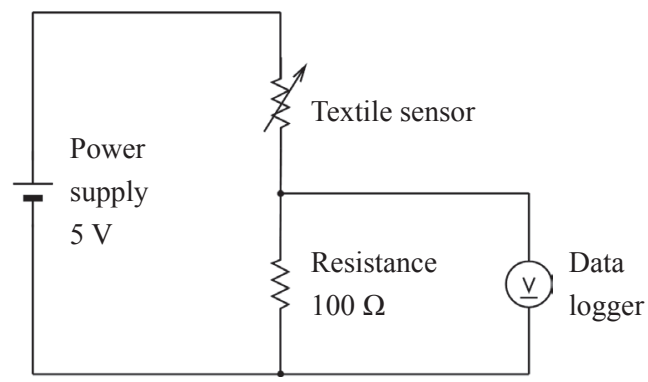

Fig. 4 Electric circuit for testing the textile sensor.

万回とした．また，動的圧縮試験前後の TS の検知圧力を測定· 比較することにより，動的圧縮耐久性を評価した。

TS の性能の評価に用いる検知圧力を測定するために, Fig. 4 に示すようにTS をスイッチとした電気回路を構成した，回 路に接続した TSに, 直径 $16 \mathrm{~mm}$ の円形加圧子を装着し た圧縮試験機（カトーテック製 KES-G5）により圧縮速度 $1 \mathrm{~mm} / \mathrm{s}$ で圧力を付加した. TS の上層部と下層部の導電糸が 接触しないときは，固定抵抗の電位差は約 $\pm 0.01 \mathrm{~V}$ で変動し ており, 両者の導電糸が接触すると約 $4 \mathrm{~V}$ 以上の電位差が急 激に発生するので, 本研究では固定抵抗の電位差が $0.1 \mathrm{~V}$ に なった時の圧縮圧力を TS の検知圧力とした。なお，検知圧 力は 1 つの TS の導電系の交錯部 16 箇所を 3 回繰り返して測 定し，その平均值で評価した。

また，TS は動的圧縮を受けることにより圧力検知応答性 の減少が考えられるため, 動的圧縮試験前後の TS の圧力検 知応答性を比較した。まず，動的圧縮試験前の TS に，周波 数 $1 \sim 40 \mathrm{~Hz}$ で最大 $20 \mathrm{kPa}$ の繰り返し圧縮圧力を付加して圧 力検知応答性を測定した。次に, 周波数 $20 \mathrm{~Hz}$, 最大 $20 \mathrm{kPa}$ で 100 万回の繰り返し圧力の負荷をかけたTSに, 周波数 $1 \sim 40 \mathrm{~Hz}$ で最大 $20 \mathrm{kPa}$ の繰り返し圧縮圧力を付加して圧力 検知応答性を測定し比較した.

\section{3. 実験結果および考察}

\section{1 テキスタイルセンサーの動的圧縮耐久性}

TS の動的圧縮耐久性の評価には，動的圧力の負荷をかけ た後（以下, 動的圧力負荷後と呼称する）の TS の検知圧力を, 動的圧力の負荷をかける前（以下，動的圧力負荷前と呼称す る）の TS の検知圧力の平均 $31.3 \mathrm{kPa}$ で除した值で定義する 検知圧力比を導入した。また，測定結果は検知可能であった 測定点の平均值で評価し，検知できなくなった測定点につい ては次節 3.2 で考察する。

TS に周波数 $20 \mathrm{~Hz}$ で最大 $20 \mathrm{kPa}$ の繰り返し圧力の負荷をか けたときの検知圧力比と繰り返し圧縮回数との関係を Fig. 5 に示す. 図より, 繰り返し圧縮回数 100 万回以下では検知圧 力比が 1 以下であり, 200 万回以上では検知圧力比が 1 以上 になり徐々に増加する傾向がみられた。

検知圧力比が 1 以下になる現象は, 動的圧力負荷前の検知 圧力より動的圧力負荷後の検知圧力が低くなることを示して おり，動的圧力の負荷をかけることで，小さい圧縮圧力で TS が応答するようになったことを意味している。松平と秦 $[19,20]$ は, 織物の圧縮特性は 3 段階から構成されて抢り, 第 1 段階（圧力 $<100 \mathrm{~Pa}$ ）は表面毛羽や突出瀻維の曲げ変形 の領域，第 2 段階（100 Pa $<$ 圧力 $<5 \mathrm{kPa}$ ）は瀻維と繊維間 の摩擦を伴うすべりによる変形の領域，第 3 段階 $(5 \mathrm{kPa}<$ 圧力）は瀻維自体の横圧縮変形の領域と報告している。これ らの報告では，ポリエステル糸 $334 \mathrm{dtex} の$ 加撚系を使用した 斜文織物で試験を実施しており, 本研究で用いた TS 地糸の ポリエステル糸 $330 \mathrm{dtex}$ の加撚糸と繊度が近いので, 本研究 で検討しているTS の圧縮変形の参考とした，本研究では周 波数 $20 \mathrm{~Hz}$ で最大 $20 \mathrm{kPa}$ の繰り返し圧力の負荷をかけている こと, TS はフィラメント糸で構成されていることから, TS の変形は主に第 $2 ， 3$ 段階の圧縮変形であると考えられる. したがって, TS 内の糸と織物構造が変形を起こして織物の 二重構造がつぶれ，TS 内に扔ける上層部と下層部の導電糸

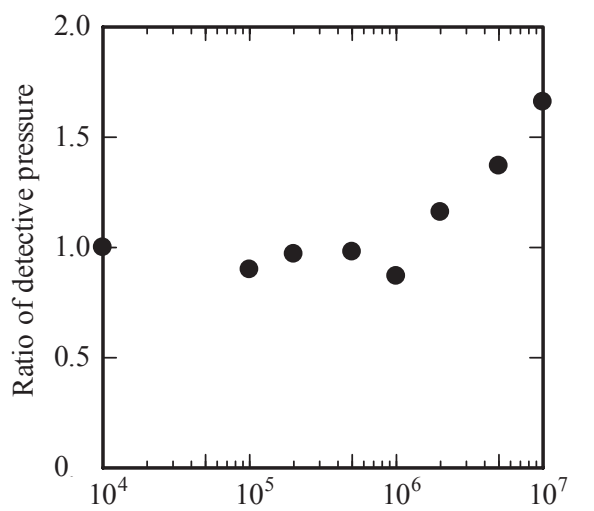

The number of cycles of dynamic compression

Fig. 5 Ratio of detective pressure as a function of the number of cycles of dynamic compression at the maximum compression pressure of $20 \mathrm{kPa}$. 
の距離が短くなると考えられる. 以上のことから, 動的圧力 の負荷をかけたときの検知圧力が低下し, 検知圧力比も 1 以 下に低下したと推測される。

繰り返し圧縮回数 200 万回以上では検知圧力比が繰り返し 圧縮回数とともに増加する傾向については，上記の圧縮圧力 による糸や織物構造の圧縮変形とは違う要因が考えられる. そこで, 動的圧力負荷前後の TS の導電糸周辺の様子を観察 した. Fig. 6(a) (b) に動的圧力負荷前, Fig. 6(c) (d) に繰り返 し圧縮回数 200 万回の負荷をかけた後の TS の表面写真を示 すＴS は圧縮したときに平二重袋織物の空間がつぶれ，上 下に配置した導電糸が接触して検知するため，たて糸とよこ 糸の交錯点に導電糸の銅線が存在する必要がある。動的圧 力負荷前の Fig. 6(a) では, 交錯点にたて導電糸の銅線が存 在しているが, 繰り返し圧縮回数の 200 万回の負荷をかけた Fig. 6(c) では, 交錯点のたて導電糸の銅線が上下にずれて変 形しており，たて導電糸を構成する銅線には，この繰り返し 変形に起因したと推測される破断部分も観察された。つまり， 繰り返し圧縮圧力により，この導電糸内の銅線の位置につい て微細なずれが発生し，動的圧力負荷前の圧縮圧力以上でな いと，上下に配置した導電糸の銅線が接触することができな くなり, 結果として繰り返し圧縮回数 200 万回を超えると検 知圧力が増加したと考えられる。

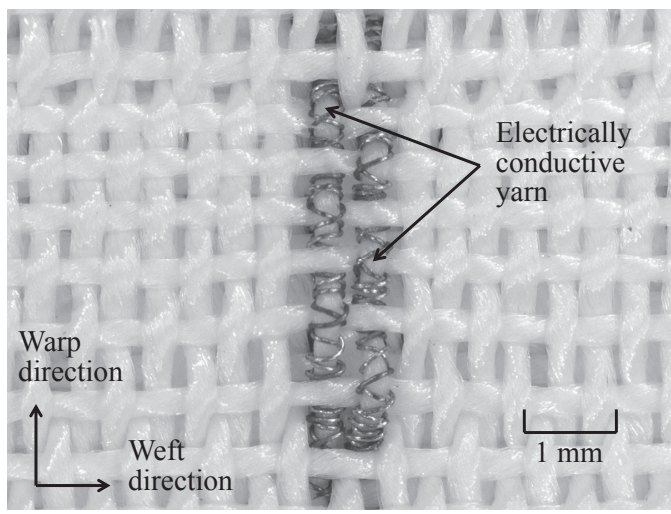

(a) Electrically conductive warp yarn before loading dynamic compression

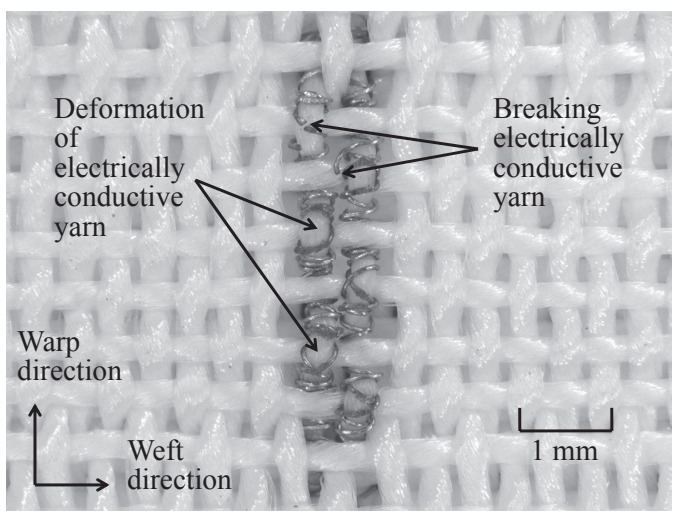

(c) Electrically conductive warp yarn after loading dynamic compression of two million times
また，繰り返し圧縮回数 200 万回の負荷をかけた導電糸は, Fig. 6(c) (d) のとおり，たて導電糸のみに銅線の変形や破断 が観察された。これについて，本研究で用いたTSはたて糸 が曲がり，よこ糸は真直ぐな織物構造である [21] ため, 曲 がりが大きいたて導電糸に銅線の変形や破断が発生したと推 測される.

以上のことにより，本研究で検討したTSでは，繰り返し 圧縮回数が 200 万回以上の動的圧縮圧力を受けることに伴う 導電糸の銅線の変形による検知圧力の増加と, 前述の 100 万 回以下の動的圧縮圧力で測定された TS 内の糸と織物構造の 変形による検知圧力の減少の両方が 200 万回以上では発生し ていると推測される。繰り返し圧縮回数が 100 万回以下であ れば，検知圧力比が 1 以下であるが，回数が 200 万回以上に なると, TS 内の糸と織物構造の変形による検知圧力の減少 よりも，交錯点のたて導電糸の銅線の変形によるずれのため 検知圧力の増加が大きい. したがって，所定の検知圧力で使 用するには繰り返し圧縮回数 100 万回以下で使用することが 望ましい。 また，使用可能な繰り返し圧縮回数が 100 万回で あることは，例えば，1 日に約千人の入退出者を計測する用 途の場合, 1 年間の保障期間中に問題なく稼動することを意 味し，実用的にも十分な性能を有すると考えられる。

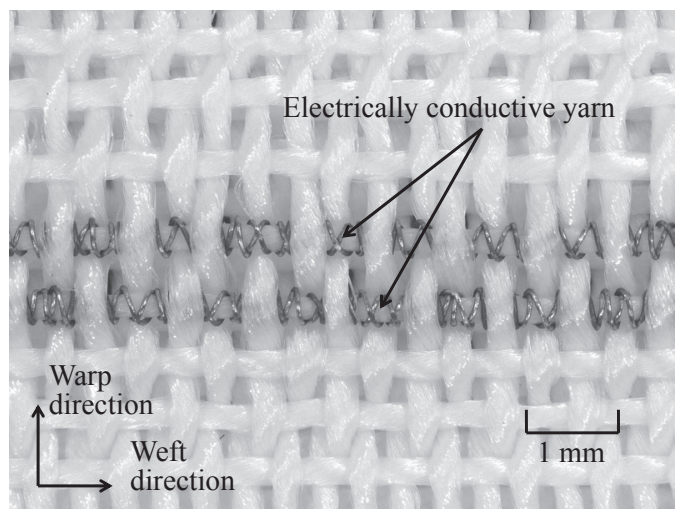

(b) Electrically conductive weft yarn before loading dynamic compression

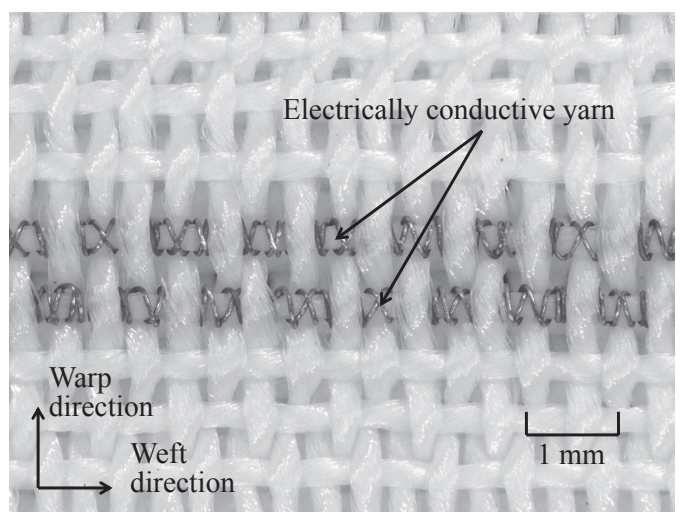

(d) Electrically conductive weft yarn after loading dynamic compression of two million times

Fig. 6 Surface photographs of the textile sensor before or after loading dynamic compression. 


\section{2 テキスタイルセンサーの動的圧縮負荷後の検 知確率}

本研究では, TS の導電糸の交錯部 16 箇所の検知圧力を測 定したが, 動的圧力の負荷をかけることにより検知圧力の測 定できない箇所が発生した。 そこで, TS の動的圧力負荷後 に圧力を検知できる確率を評価するために, 動的圧力負荷 前の 16 の検知箇所について, 動的圧力負荷後の検知圧力の 測定の可否を調べた。また，動的圧力負荷後の検知圧力の測 定可能な検知箇所を, 動的圧力負荷前の 16 の検知箇所で除 した值で定義する検知確率を導入して評価した。TSに周波 数 $20 \mathrm{~Hz}$ で最大 $20 \mathrm{kPa}$ の繰り返し圧力の負荷をかけたとき の検知確率と圧縮圧力の繰り返し回数との関係を Fig. 7 に示 す。図より, 繰り返し圧縮回数が 100 万回以下では検知確率 が1であり，TSのすべての検知箇所が機能しているが，200 万回以上になると検知確率は繰り返し回数の増加とともに減 少し，検知圧力が測定できない箇所が増加した。これらの検 知圧力が測定できない箇所では，Fig. 6(c) に示したとおり 導電糸の銅線が複数箇所で破断して電気的に絶縁状態となる ことが確認できたことから, 交錯点付近の導電糸の銅線は最 も大きな繰り返し圧縮荷重を受けるため, 繰り返し圧縮回数 が 200 万回近傍になると, 塩化ビニル製の板や TS の地糸に 衝突して導電糸の銅線が破断しはじめると推測される。この ことにより, 周波数 $20 \mathrm{~Hz}$ で最大 $20 \mathrm{kPa}$ の繰り返し圧力の負 荷をかけた場合, 繰り返し圧縮回数が 100 万回以下では導電 糸の銅線の破断に起因する検知圧力の測定できない箇所が発 生しないと考えられ，前節で述べた繰り返し圧縮回数 100 万 回という TSの使用限界を裏付ける結果を得た。このように, 本研究で得られた TS の繰り返し圧縮の使用限界は, TS 内導 電糸の銅線の変形や破断が主に起因していた。しかし，めつ き技術による電気抵抗值が低い導電糸 [21]などを TS に応用 することで，使用限界を向上させることが可能であると考え られる。

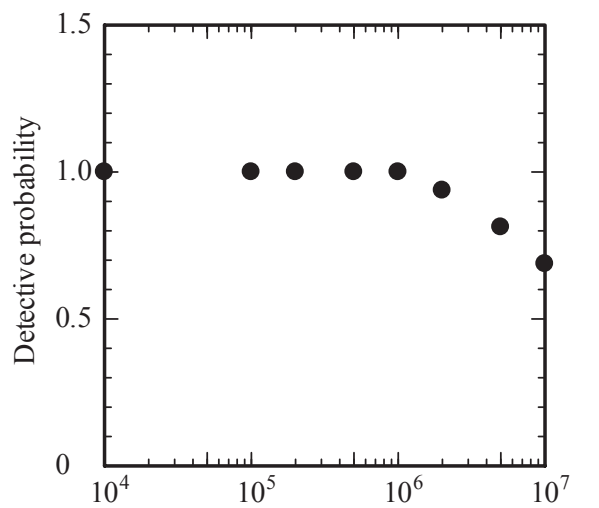

The number of cycles of dynamic compression

Fig. 7 Detective probability as a function of the number of cycles of dynamic compression at the maximum compression pressure of $20 \mathrm{kPa}$.

\section{3 テキスタイルセンサーの動的圧縮負荷後の圧 力検知応答性}

次に, 動的圧力負荷後の TS の圧力検知応答性を評価す るために, 動的圧力負荷前の TS と, 周波数 $20 \mathrm{~Hz}$, 最大 20 $\mathrm{kPa}$ で 100 万回の繰り返し圧力の負荷をかけた TSのそれぞ れに, 周波数 1 〜 $40 \mathrm{~Hz}$ で最大 $20 \mathrm{kPa}$ の繰り返し圧縮圧力を

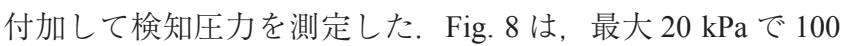
万回の繰り返し圧力の負荷をかける前と負荷をかけた後の $\mathrm{TS} の$ 検知圧力比と繰り返し圧縮圧力の周波数との関係を示 した図である。図より, 動的圧力負荷前後の検知圧力比は, いずれも周波数 $30 \mathrm{~Hz}$ までは緩やかに減少し, $30 \mathrm{~Hz}$ を超え ると急激に減少している.この現象については, 前の報告 [15] のとおり, 周波数が高くなるほど TS の糸と織物構造が加圧 前の状態に復帰できないためで, 特に周波数 $40 \mathrm{~Hz}$ の場合は TS の二重構造の空間が非常に狭い状態で繰り返し圧縮され るためであると推測される。また，各周波数における検知圧 力比は動的圧力負荷前後で大きな差は見られない.

動的圧力負荷前後の TS の圧力検知応答性について周波数 $20 \mathrm{~Hz}$ の場合の例を Fig. 9 に示す。動的圧力負荷前の TS に, 周波数 $20 \mathrm{~Hz}$ で最大 $20 \mathrm{kPa}$ の繰り返し圧縮圧力を付加したと きの圧力検知応答性を Fig. 9 (a) に示す. 図より, TS に付加 した周波数 $20 \mathrm{~Hz}$ の繰り返し圧縮圧力に応じて, 固定抵抗両 端の電圧波形には周波数 $20 \mathrm{~Hz}$ の ON と OFF の明確な矩形波 を観測することができた，次に，周波数 $20 \mathrm{~Hz}$ ，最大 $20 \mathrm{kPa}$ で 100 万回の繰り返し圧力の負荷をかけた後の TS の圧力検 知応答性を Fig. 9(b) に示す。図より, Fig. 9(a) 同様に周波 数 $20 \mathrm{~Hz}$ の明確な矩形波を観測することができた。したがっ て, 動的圧力負荷前後の TS の圧力検知応答性はほぼ同じで あり, 周波数 $20 \mathrm{~Hz}$ で最大 $20 \mathrm{kPa}$ の繰り返し圧力を 100 万回 負荷しても圧力検知応答性に変化がないことがわかった。こ のことより, 繰り返し圧縮回数 100 万回以下であれば, 最大 $20 \mathrm{kPa}$ の動的圧力負荷後でも TS の圧力検知応答性は維持さ れることがわかった

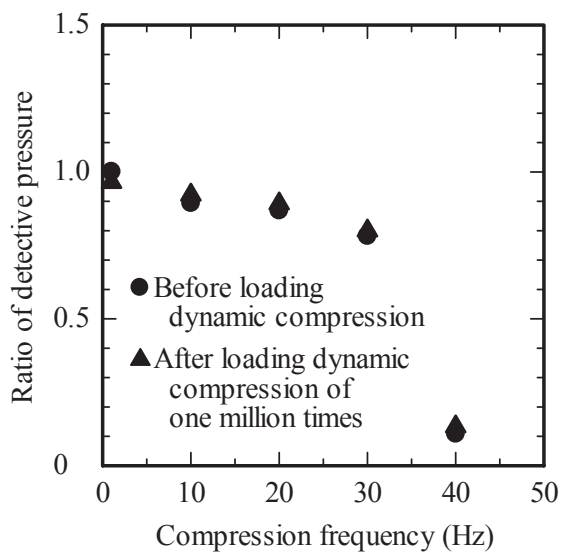

Fig. 8 Ratio of detective pressure as a function of compression frequency. 


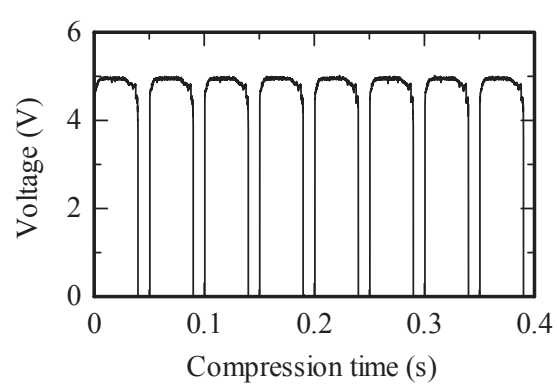

(a) Before loading compression

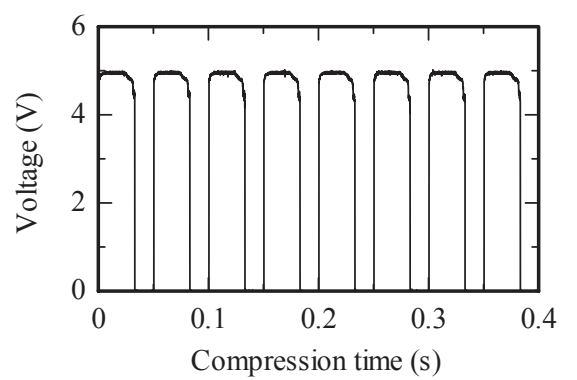

(b) After loading compression of one million times

Fig. 9 Response of the textile sensor at compression frequency of $20 \mathrm{~Hz}$.

\section{4. 結 言}

本報では, TSに動的圧力の負荷をかけたときの動的圧縮 耐久性および圧力検知応答性について検討した。明らかに なったことを以下にまとめる.

（1） TS は周波数 $20 \mathrm{~Hz}$ で最大 $20 \mathrm{kPa}$ の動的圧力の負荷を かけたとき, 繰り返し圧縮回数が 100 万回以下であれば, 動 的圧力の負荷をかけることによる検知圧力の変化が少ない.

（2）周波数 $20 \mathrm{~Hz}$ で最大 $20 \mathrm{kPa}$ の動的圧力負荷後の TS は, 繰り返し圧縮回数が 100 万回以下であれば, 動的圧力負荷前 の圧力検知応答性が維持される.

（3）動的圧力の繰り返し圧縮回数が 200 万回を超えると, TS 内の導電糸の銅線の変形や破断により, 繰り返し圧縮回 数の増加とともに検知圧力の増加や測定不能な検知箇所の増 加が見られた

このように, TS は優れた動的圧縮耐久性と圧力検知応答 性があるので, 入退出者数計測システムなど耐久性と応答性 の両方が要求される分野への応用に適していることがわかっ
た。また, 本研究で得られた TS の繰り返し圧縮の使用限界 については, TS 内導電糸の銅線の変形や破断が主に起因し ており，めっき技術による電気抵抗值が低い導電糸などを TS に応用することで, 使用限界を向上させることが可能で あると考えられる。

\section{References}

[1] Nitta Co Ltd (2006) Japanese Patent 3882172

[2] Fujioka J, Kuroda N (2014) J Text Mach Soc Japan, 67, 115119

[3] Shibata K (2014) J Text Mach Soc Japan, 67, 723-725

[4] Enokibori Y, Mase K (2015) J Text Mach Soc Japan, 68, 477483

[5] Suminoe Textile Co Ltd (2014) Japanese Patent 5457063

[6] Tajitsu Y, Yamamoto T (2015) Sen'i Gakkaishi, 71, 232

[7] Masuda A, Murakami T, Kondo K (2008) J Text Mach Soc Japan, 61, 809-814

[8] Fukui Prefecture (2009) Japanese Patent 4273233

[9] Fukui Prefecture (2013) Japanese Patent 5352795

[10] Toda M, Akita J, Sakurazawa S, Iwata K (2007) J Text Mach Soc Japan, 60, 142-147

[11] Takahashi H (2010) J Text Mach Soc Japan, 60, 607-610

[12] Fukui Prefecture (2010) Japanese Patent 4565109

[13] Fukui Prefecture, Utic Co Ltd (2013) Japanese Patent 5233055

[14] FUKUI e-Textile research group (2015) Sen'i Gakkaishi, 71,277-281

[15] Masuda A, Murakami T, Kondo K, Sasaji T, Iemoto Y, Tanoue S (2010) J Text Eng, 56, 181-185

[16] Murakami T, Masuda A, Yoshida Y, Iemoto Y, Uematsu H, Tanoue S (2016) J Text Eng, 62, 51-56

[17] Murakami T, Masuda A, Hirakue M, Iemoto Y, Uematsu H, Tanoue S (2016) J Fiber Sci Tech, 72, 120-125

[18] Murakami T, Masuda A, Iemoto Y, Uematsu H, Tanoue S (2016) J Text Eng, 62, 1-5

[19] Matsudaira M, Hong Q (1993) J Text Mach Soc Japan (predecessor journal of J Text Eng), 46, 226-231

[20] Matsudaira M, Hong Q (1995) J Text Mach Soc Japan (predecessor journal of J Text Eng), 48, 191-195

[21] Kitada F (1970) "Clothing material summary" 174, Corona Publishing Co Ltd

[22] Hori T (2011) J Text Mach Soc Japan, 64, 471-476 